$\mathrm{B}$ аскулиты кожи: классификация, Аиагностика и дифференциальная диагностика (часть 2)

Хайрутдинов В.Р. ${ }^{*}$ Белоусова И. Э., Самцов А. В.

ФГБВОУ ВО «Военно-медицинская академия им. С.М.Кирова» Министерства обороны Российской Федерации

194044, Россия, г. Санкт-Петербург, ул. Академика Лебедева, д. 6

Данная статья является продолжением обзора литературы, посвященного васкулитам кожи. В первой части были представлены сведения о современной номенклатуре и распространенности васкулитов, отражены патоморфологические изменения в коже, а также диагностические алгоритмы обследования больных с этой патологией.

Вторая часть статьи содержит подробное описание элементов кожной сыпи при системных и органоспецифрических васкулитах, представлены клинические проявления, наблюдаемые при поражении других органов и систем, развитии возможных осложнений.

Обобщены данные о современной тактике лечения, отражены современные подходы с использованием патогенетической и симптоматической терапии больных различными васкулитами.

Ключевые слова: васкулиты кожи, лейкоцитокластический васкулит, лечение васкулитов, болезни Шенлейна Геноха, эритема возвышающаяся стойкая, уртикарный васкулит, болезнь Бехчета.

Конфрликт интересов: авторы заявляют об отсутствии потенциального конфрликта интересов, требующего раскрытия в данной статье.

Для цитирования: Хайрутдинов В.Р., Белоусова И.Э., Самцов А.В. Васкулиты кожи: классификация, диагностика и дифференциальная диагностика (часть 2). Вестник дерматологии и венерологии. $2020 ; 97$ (2): 14-23. https://doi.org/10.25208/vdv1118 


\section{Cutaneous Vasculitis: Classification, Diagnosis and Differential Diagnosis (Part 2)}

Vladislav R. Khairutdinov*, Irena E. Belousova, Aleksey V. Samtsov

Federal state budgetary educational institution of higher military education "Military Medical Academy named after S.M. Kirov" of the Russian Ministry of Defense

Akademika Lebedeva str., bldg 6, Saint Petersburg, 194044, Russian Federation

This article is a continuation of the literature review on skin vasculitis. In the first part, information was presented on the current nomenclature and prevalence of vasculitis, pathomorphological changes in the skin, as well as diagnostic algorithms for examining patients with this pathology are reflected.

The second part of the article contains a detailed description of the elements of the skin rash with systemic and organ-specific vasculitis, presents the clinical manifestations observed with damage to other organs and systems, the development of possible complications.

The data on modern treatment tactics are summarized, modern approaches using pathogenetic and symptomatic therapy of patients with various vasculitis are reflected.

Keywords: skin vasculitis, leukocytoclastic vasculitis, treatment of vasculitis, Shenlein — Genoch disease, erythema elevatum diutinum, urticarial vasculitis, Behcet's disease.

Conflict of interest: the authors state that there is no potential conflict of interest requiring disclosure in this article.

For citation: Vladislav R. Khairutdinov, Irena E. Belousova, Aleksey V. Samtsov. Cutaneous Vasculitis: Classification, Diagnosis and Differential Diagnosis (Part 2). Vestnik Dermatologii i Venerologii. 2020; 97 (2): 14-23.

https://doi.org/10.25208/vdv1118 


\section{Клиническая картина}

При гигантоклеточном артериите сосуды кожи не поражаются. Изменения кожи и слизистых оболочек наблюдаются редко, они появляются при окклюзии кровоснабжающих их внекожных артерий. При артериите язычной артерии развивается некроз слизистой оболочки языка, появляются язвы на его поверхности. Крайне редко при гигантоклеточном артериите в воспалительный процесс вовлекаются мелкие сосуды подкожной клетчатки и подслизистого слоя (см. табл.) [1, 2].

Клиническая картина поражения кожи при узелковом периартериите характеризуется появлением на верхних и нижних конечностях болезненных узлов, ретикулярного ливедо и глубоких кровоточащих язв (рис. 1). Реже встречаются геморрагические пятна (петехии), эритема, пузыри с геморрагическим содержимым. При кожной фрорме узелкового периартериита обычно наблюдается хроническое рецидивирующее течение заболевания, более благоприятное, чем при системном процессе. Случаи развития системного васкулита на фоне кожной формы узелкового периартериита крайне редки. Многие авторы исключают такую возможность [1]. Системный узелковый периартериит манифестирует лихорадкой, резким снижением веса, появлением болей в мышцах и суставах. Наблюдаются поражения других органов: почек (артерииты и аневризмы почечных сосудов, клубочковая ишемия, но без гломерулонефрита), мочевой синдром с протеинурией и гематурией, артериальная гипертензия, быстро прогрессирующая почечная недостаточность; желудочно-кишечные нарушения (мезентериальный артериит) - боли в животе, напоминающие клиническую картину аппендицита, панкреатита, перитонита [3, 4].

При васкулитах с грануломатозом (грануломатоз с полиангиитом и эозинофильный грануломатоз с полиангиитом) не всегда наблюдаются системные проявления (язвенно-некротические изменения слизистой оболочки респираторного тракта, гломерулонефрит). Поражение кожи при грануломатозе с полиангиитом наблюдается более чем у половины больных. Высы-

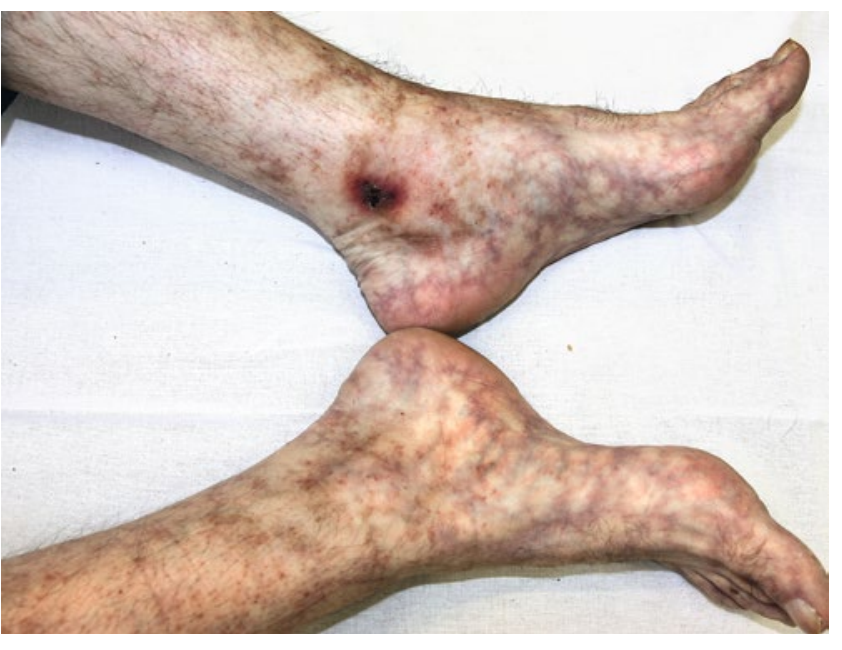

пания представлены петехиями и пальпируемой пурпурой. Описаны случаи изолированного поражения кожи. В то же время развитие системного васкулита возможно в течение 10 лет после дебюта заболевания на коже [5, 6].

Криоглобулинемический васкулит может протекать в виде системного и ограниченного кожей поражения сосудов. Криоглобулинемический васкулит часто ассоциирован с вирусными гепатитами В, С, гематологическими и аутоиммунными заболеваниями. Клинические проявления представлены «воспалительной» пальпируемой пурпурой, которая развивается на участках кожи, подвергшихся воздействию низкой температуры (кисти, стопы, уши, нос, щеки) (рис. 2) [7, 8].

Для $\lg A$-васкулита (болезни Шенлейна - Геноха) характерно поражение кожи нижних конечностей, преимущественно голеней и стоп. До 30\% больных имеют высыпания на коже туловища и верхних конечностей. У $1 / 3$ пациентов развитию васкулита предшествует инфекция верхних дыхательных путей. Заболевание имеет острое начало, высыпания появляются в течение нескольких дней и часто самостоятельно разрешаются через 2-3 недели. Первичным морфологическим элементом кожной сыпи является геморрагическое пятно округлой фрормы, небольших размеров (2-5 мм) петехия (рис. 3). При вовлечении в воспаление более крупных сосудов элементы возвышаются над уровнем кожи и пальпируются - пальпируемая пурпура, могут иметь сетчатую фрорму (ретикулярная пурпура). Нередко в центре геморрагических пятен формируются очаги некроза - некротическая пурпура, и пузыри с геморрагическим содержимым (рис. 4, 5). При буллезном и некротическом варианте IgA-васкулита результаты прямой реакции иммунофрлуоресценции могут быть отрицательные. После разрешения геморрагических пятен в течение нескольких недель сохраняется коричневое окрашивание кожи в связи с отложениями гемосидерина. Болезнь Шенлейна - Геноха может протекать с преимущественным поражением кожи, без симптомов системного васкулита (нет клинических проявлений

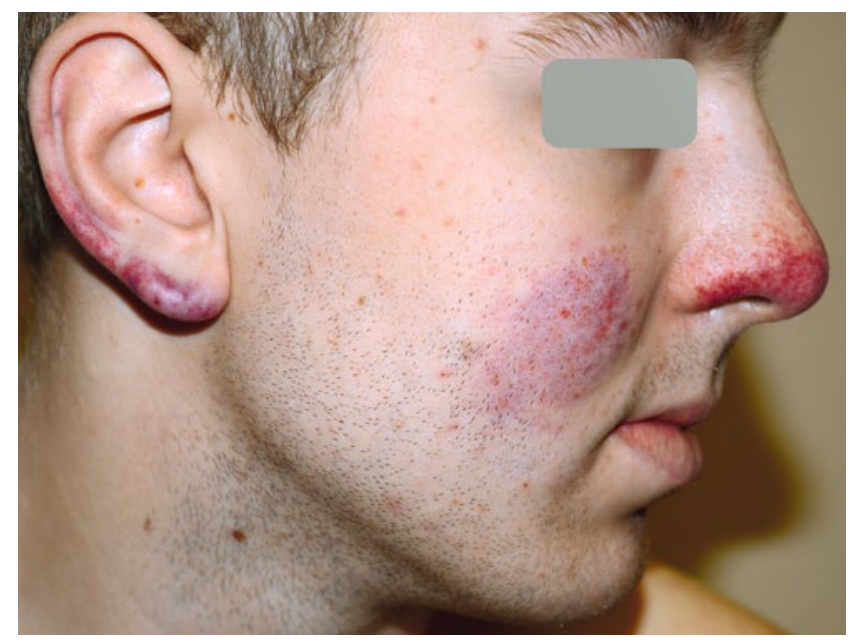

Рис. 2. Криоглобулинемический васкулит: множественные петехии Fig. 2. Cryoglobulinemic vasculitis: multiple petechial hemorrhage 
Таблица. Клинические проявления васкулитов кожи

Table. Clinical manifestations of skin vasculitis

\begin{tabular}{|c|c|c|c|c|}
\hline $\begin{array}{c}\text { Современное } \\
\text { название }\end{array}$ & Другие названия & Элементы сыпи & $\begin{array}{c}\text { Локализация } \\
\text { высыпаний }\end{array}$ & $\begin{array}{c}\text { Дополнительные } \\
\text { критерии }\end{array}$ \\
\hline \multicolumn{5}{|c|}{ Васкулиты сосудов крупного диаметра } \\
\hline $\begin{array}{c}\text { Гигантоклеточный } \\
\text { артериит }\end{array}$ & $\begin{array}{c}\text { Темпоральный артериит, } \\
\text { краниальный артериит, } \\
\text { болезнь Хортона }\end{array}$ & $\begin{array}{c}\text { Очаги некроза и язвы на } \\
\text { слизистой оболочке языка }\end{array}$ & Полость рта & $\begin{array}{c}\text { В крови выявляются } \\
\text { аутоантитела к клеткам } \\
\text { сосудистого эндотелия, } \\
\text { ферритину }\end{array}$ \\
\hline \multicolumn{5}{|c|}{ Васкулиты сосудов среднего диаметра } \\
\hline $\begin{array}{c}\text { Узелковый } \\
\text { периартериит }\end{array}$ & $\begin{array}{c}\text { Узелковый панартериит, } \\
\text { узловатый полиартериит, } \\
\text { системный некротизирующий } \\
\text { васкулит }\end{array}$ & $\begin{array}{c}\text { Ретикулярное ливедо, папулы, } \\
\text { узлы, кровоточащие язвы, } \\
\text { петехии, эритема, пузыри с } \\
\text { геморрагическим содержимым }\end{array}$ & $\begin{array}{c}\text { Верхние и нижние } \\
\text { конечности, лицо, } \\
\text { шея }\end{array}$ & - \\
\hline
\end{tabular}

\begin{tabular}{|c|c|c|c|c|}
\hline $\begin{array}{c}\text { Микроскопический } \\
\text { полиангиит }\end{array}$ & Микроскопический полиартериит & $\begin{array}{c}\text { Петехии, } \\
\text { пальпируемая пурпура, }\end{array}$ & & \\
\hline $\begin{array}{c}\text { Грануломатоз } \\
\text { с полиангиитом }\end{array}$ & $\begin{array}{c}\text { Болезнь Вегенера, некротический } \\
\text { неинфекционный гранулематоз }\end{array}$ & $\begin{array}{c}\text { папулы с некрозом, узлы, } \\
\text { очаговые некрозы (инфраркты) } \\
\text { кожи, }\end{array}$ & $\begin{array}{l}\text { Верхние и нижние } \\
\text { конечности, чаще } \\
\text { в области крупных }\end{array}$ & $\begin{array}{l}\text { В крови выявляются } \\
\text { аутоантитела: } \\
\text { anti-PR3 ANCA. }\end{array}$ \\
\hline $\begin{array}{l}\text { Эозинофильный } \\
\text { грануломатоз } \\
\text { с полиангиитом }\end{array}$ & Болезнь Чарга - Стросса & $\begin{array}{c}\text { язвенно-некротические } \\
\text { изменения слизистой оболочки } \\
\text { полости рта и носа }\end{array}$ & суставов & anti-MPO pANCA \\
\hline \multicolumn{5}{|c|}{ II. Иммунокомплексные васкулиты } \\
\hline $\begin{array}{c}\text { Криоглобулинемиче- } \\
\text { ский васкулит }\end{array}$ & - & $\begin{array}{c}\text { Петехии, } \\
\text { пальпируемая пурпура }\end{array}$ & $\begin{array}{c}\text { Участки кожи, } \\
\text { подвергающиеся } \\
\text { воздействию низкой } \\
\text { температуры: кисти, } \\
\text { стопы, уши, нос, } \\
\text { щеки }\end{array}$ & $\begin{array}{c}\text { В крови выявляются } \\
\text { криоглобулины II и III типа }\end{array}$ \\
\hline
\end{tabular}

\begin{tabular}{|c|c|c|c|c|}
\hline IgA-васкулит & $\begin{array}{c}\text { Геморрагический васкулит } \\
\text { (болезнь Шенлейна - Геноха), } \\
\text { геморрагический } \\
\text { лейкокластический микробид } \\
\text { Мишера - Шторка, } \\
\text { аллергический артериолит, } \\
\text { папуло-некротический дерматит } \\
\text { Вертера - Дюмлинга, } \\
\text { трехсимптомная болезнь } \\
\text { Гужеро - Дюперра и др. }\end{array}$ & $\begin{array}{c}\text { Петехии, } \\
\text { пальпируемая пурпура, } \\
\text { папулы с некрозом, } \\
\text { пузыри с геморрагическим } \\
\text { содержимым }\end{array}$ & $\begin{array}{l}\text { Нижние конечности } \\
\text { (голени и стопы), } \\
\text { реже - туловище и } \\
\text { верхние конечности }\end{array}$ & $\begin{array}{c}\text { Депозиты IgA1 в стенке } \\
\text { кровеносных сосудов } \\
\text { кожи. } \\
\text { В крови могут выявляться } \\
\text { аутоантитела к клеткам } \\
\text { сосудистого эндотелия }\end{array}$ \\
\hline $\begin{array}{c}\text { Гипокомплементеми- } \\
\text { ческий уртикарный } \\
\text { васкулит }\end{array}$ & Анти-С1q васкулит & $\begin{array}{c}\text { Волдыри, петехии, сетчатое } \\
\text { ливедо }\end{array}$ & 一 & $\begin{array}{c}\text { В крови выявляются анти- } \\
\text { С1q антитела. } \\
\text { Волдыри существуют } \\
\text { более } 24 \text { часов }\end{array}$ \\
\hline \multicolumn{5}{|c|}{ Васкулит с вариабельным поражением сосудов } \\
\hline Болезнь Бехчета & $\begin{array}{c}\text { Большой афтоз Турена, } \\
\text { болезнь Адамантиади — Бехчета }\end{array}$ & $\begin{array}{c}\text { Акнеформные фолликулярные } \\
\text { пустулы, нефолликулярные } \\
\text { папуло-пустулезные } \\
\text { высыпания, узлы, язвы, } \\
\text { эрозии и язвы на слизистой } \\
\text { оболочке полости рта }\end{array}$ & $\begin{array}{c}\text { Верхние и нижние } \\
\text { конечности, } \\
\text { гениталии, полость } \\
\text { рта }\end{array}$ & $\begin{array}{c}\text { Положительный тест } \\
\text { патергии. } \\
\text { В крови могут выявляться } \\
\text { аутоантитела к клеткам } \\
\text { сосудистого эндотелия }\end{array}$ \\
\hline \multicolumn{5}{|c|}{ Васкулиты, ассоциированные с системными заболеваниями } \\
\hline $\begin{array}{c}\text { Волчаночный } \\
\text { васкулит }\end{array}$ & - & & & $\begin{array}{c}\text { В крови выявляются } \\
\text { антинуклеарные антитела }\end{array}$ \\
\hline $\begin{array}{c}\text { Ревматоидный } \\
\text { васкулит }\end{array}$ & - & $\begin{array}{c}\text { Петехии, ретикулярное ливедо, } \\
\text { папулы с некрозом }\end{array}$ & $\begin{array}{l}\text { Верхние и нижние } \\
\text { конечности, } \\
\text { туловище, лицо }\end{array}$ & $\begin{array}{c}\text { В крови выявляются } \\
\text { положительный } \\
\text { ревматоидный фактор, } \\
\text { антитела к циклическому } \\
\text { цитруллинированному } \\
\text { пептиду } \\
\end{array}$ \\
\hline $\begin{array}{l}\text { Васкулит при } \\
\text { саркоидозе }\end{array}$ & - & & & - \\
\hline
\end{tabular}




\begin{tabular}{|c|c|c|c|c|}
\hline $\begin{array}{c}\text { Современное } \\
\text { название }\end{array}$ & Другие названия & Элементы сыпи & $\begin{array}{c}\text { Локализация } \\
\text { высыпаний }\end{array}$ & $\begin{array}{c}\text { Дополнительные } \\
\text { критерии }\end{array}$ \\
\hline \multicolumn{5}{|c|}{ Васкулиты с установленной (вероятной) этиологией } \\
\hline $\begin{array}{l}\text { Криоглобулинеми- } \\
\text { ческий васкулит, } \\
\text { ассоциированный } \\
\text { с вирусным } \\
\text { гепатитом С }\end{array}$ & - & $\begin{array}{c}\text { Петехии, } \\
\text { пальпируемая пурпура, } \\
\text { волдыри }\end{array}$ & $\begin{array}{c}\text { Участки кожи, } \\
\text { подвергающиеся } \\
\text { воздействию низкой } \\
\text { температуры: кисти, } \\
\text { стопы, уши, нос, } \\
\text { щеки }\end{array}$ & $\begin{array}{c}\text { В крови выявляются } \\
\text { криоглобулины II и III } \\
\text { типа, маркеры вирусного } \\
\text { гепатита C }\end{array}$ \\
\hline $\begin{array}{c}\text { Васкулит, } \\
\text { ассоциированный } \\
\text { с вирусным } \\
\text { гепатитом В }\end{array}$ & - & $\begin{array}{c}\text { Петехии, } \\
\text { пальпируемая пурпура, } \\
\text { ретикулярное ливедо, папулы } \\
\text { с некрозом, узлы, волдыри }\end{array}$ & $\begin{array}{c}\text { Верхние и нижние } \\
\text { конечности, } \\
\text { туловище }\end{array}$ & $\begin{array}{c}\text { В крови выявляются } \\
\text { маркеры вирусного } \\
\text { гепатита В. В 35-42\% } \\
\text { встречается HBV- } \\
\text { ассоциированный } \\
\text { узелковый периартериит }\end{array}$ \\
\hline $\begin{array}{c}\text { Лекарственно- } \\
\text { индуцированный } \\
\text { иммунокомплексный } \\
\text { васкулит }\end{array}$ & - & $\begin{array}{c}\text { Петехии, } \\
\text { пальпируемая пурпура, } \\
\text { волдыри, папулы с некрозом, } \\
\text { язвы }\end{array}$ & $\begin{array}{c}\text { Верхние и нижние } \\
\text { конечности, } \\
\text { туловище }\end{array}$ & $\begin{array}{c}\text { Связь с приемом } \\
\text { лекарственного препарата } \\
\text { (статины, ингибиторы } \\
\text { ФНО } \alpha)\end{array}$ \\
\hline $\begin{array}{c}\text { Лекарственно- } \\
\text { индуцированный } \\
\text { АНЦА-ассоциирован- } \\
\text { ный васкулит }\end{array}$ & - & $\begin{array}{c}\text { Петехии, } \\
\text { пальпируемая пурпура, } \\
\text { волдыри, папулы с некрозом, } \\
\text { язвы }\end{array}$ & $\begin{array}{l}\text { Верхние и нижние } \\
\text { конечности, } \\
\text { туловище, лицо, } \\
\text { полость рта }\end{array}$ & $\begin{array}{c}\text { Связь с приемом } \\
\text { лекарственного } \\
\text { препарата (миноциклин, } \\
\text { кокаин, левамизол, } \\
\text { пропилтиоурацил, } \\
\text { карбимазол, ритуксимаб). } \\
\text { B крови выявляются } \\
\text { ANCA, часто антитела к } \\
\text { фоссфолипидам }\end{array}$ \\
\hline Септический васкулит & - & $\begin{array}{c}\text { Петехии, } \\
\text { ретикулярное ливедо }\end{array}$ & $\begin{array}{l}\text { Верхние и нижние } \\
\text { конечности, } \\
\text { туловище, лицо }\end{array}$ & $\begin{array}{c}\text { Положительный тест на } \\
\text { прокальцитонин и др. } \\
\text { маркеры сепсиса }\end{array}$ \\
\hline $\begin{array}{c}\text { Васкулит, } \\
\text { ассоциированный } \\
\text { со злокачественными } \\
\text { новообразованиями }\end{array}$ & - & $\begin{array}{c}\text { Петехии, } \\
\text { пальпируемая пурпура, } \\
\text { волдыри, папулы с некрозом, } \\
\text { язвы }\end{array}$ & $\begin{array}{l}\text { Чаще нижние } \\
\text { конечности }\end{array}$ & $\begin{array}{c}\text { Злокачественные опухоли } \\
\text { (чаще из лимфоидной } \\
\text { ткани) }\end{array}$ \\
\hline
\end{tabular}

Органоспецифические васкулиты - васкулиты одного органа

\begin{tabular}{|c|c|c|c|c|}
\hline IgM/lgG-васкулит & $\begin{array}{c}\text { Геморрагический васкулит } \\
\text { (болезнь Шенлейна - Геноха), } \\
\text { геморрагический } \\
\text { лейкокластический микробид } \\
\text { Мишера - Шторка, } \\
\text { аллергический артериолит, } \\
\text { папуло-некротический дерматит } \\
\text { Вертера - Дюмлинга, } \\
\text { трехсимптомная болезнь } \\
\text { Гужеро - Дюперра и др. }\end{array}$ & $\begin{array}{c}\text { Петехии, } \\
\text { пальпируемая пурпура, } \\
\text { папулы с некрозом, } \\
\text { пузыри с геморрагическим } \\
\text { содержимым }\end{array}$ & $\begin{array}{l}\text { Нижние конечности, } \\
\text { (голени и стопы), } \\
\text { реже - туловище и } \\
\text { верхние конечности }\end{array}$ & $\begin{array}{c}\text { Выявляются депозиты } \\
\operatorname{lgM~и~IgG~в~стенке~} \\
\text { кровеносных сосудов } \\
\text { кожи }\end{array}$ \\
\hline $\begin{array}{c}\text { Нодулярный } \\
\text { (узловатый) васкулит }\end{array}$ & Индуративная эритема Базена & Узлы, язвы & $\begin{array}{l}\text { Сгибательные } \\
\text { поверхности } \\
\text { голеней }\end{array}$ & - \\
\hline $\begin{array}{c}\text { Эритема } \\
\text { возвышающаяся } \\
\text { стойкая }\end{array}$ & - & Папулы, бляшки, узлы & $\begin{array}{c}\text { Разгибательные } \\
\text { поверхности } \\
\text { верхних и нижних } \\
\text { конечностей } \\
\text { (часто в проекции } \\
\text { суставов) }\end{array}$ & - \\
\hline $\begin{array}{c}\text { Гипергаммаглобули- } \\
\text { немический } \\
\text { пятнистый васкулит }\end{array}$ & $\begin{array}{c}\text { Гиперглобулинемическая пурпура } \\
\text { Вальденстрема }\end{array}$ & Петехии & $\begin{array}{c}\text { Верхние и нижние } \\
\text { конечности (голени, } \\
\text { стопы) }\end{array}$ & - \\
\hline $\begin{array}{c}\text { Нормокомплементе- } \\
\text { мический уртикарный } \\
\text { васкулит }\end{array}$ & Геморрагическая крапивница & $\begin{array}{c}\text { Волдыри, петехии, } \\
\text { ретикулярное ливедо }\end{array}$ & - & $\begin{array}{l}\text { Волдыри существуют } \\
\text { более } 24 \text { часов }\end{array}$ \\
\hline
\end{tabular}




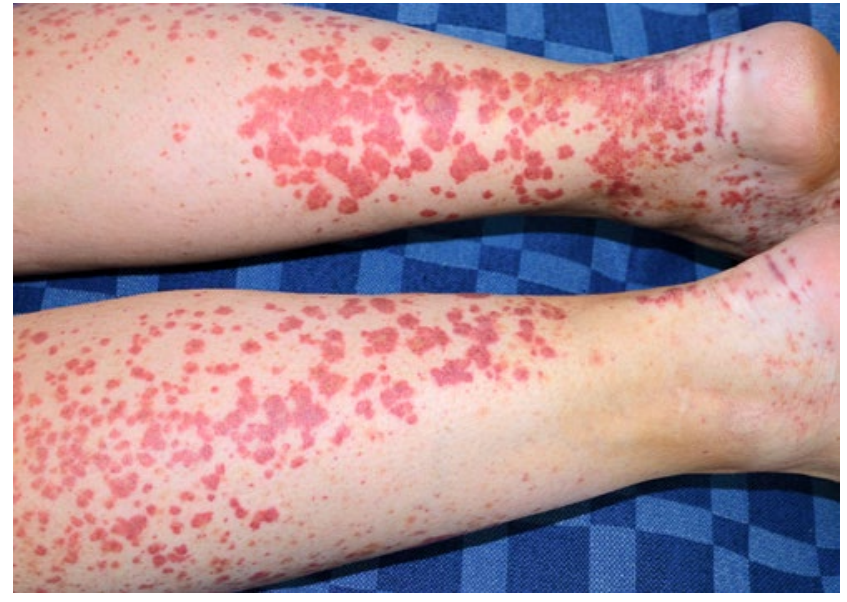

Рис. 3. IgA-васкулит: пальпируемая пурпура
Fig. 3. IgA vasculitis: palpable purpura

вовлечения сосудов ЖКТ и суставов, в повторных анализах мочи отсутствуют измененные эритроциты). Системные проявления IgA-васкулита наблюдаются достаточно часто - поражение ЖКТ (боль в животе, кровотечение, мелена) у $51-65 \%$, суставов (артралгии и артриты) - 44-63\%, почек (микро- или макрогематурия) - 20-80\% больных. Редко могут наблюдаться поражения церебральных сосудов, кровоизлияния в яички и интерстициальные легочные кровоизлияния. У взрослых пациентов системные проявления встречаются реже, чем у детей, чаще наблюдаются высыпания на коже с отеком нижних конечностей [9-14].

Уртикарный васкулит встречается почти исключительно у взрослых (дети составляют около $1 \%$ больных), женщины болеют значительно чаще - 70-74\% всех пациентов. Клинические проявления гипокомплементемического уртикарного васкулита (анти-С1q васкулита) представлены уртикарными высыпаниями, которые отличаются от волдырей при крапивнице более длительным существованием (более 24 часов). Наряду с волдырями на коже могут встречаться петехии. После разрешения уртикарных высыпаний при гипокомплементемическом васкулите часто наблюдается поствоспалительная пигментация. Анти-С1q васкулит может протекать в виде системного васкулита с преимущественным поражением кожи при таких заболеваниях, как СКВ, сывороточная болезнь, вирусный гепатит В, злокачественные новообразования. Системные поражения при анти-С1q васкулите наблюдаются часто и включают гломерулонефрит, артриты, воспаление глаз [15-18].

На долю нормокомплементемического уртикарного васкулита приходится около 49-80\% всех случаев уртикарного васкулита. Он протекает исключительно с изолированным поражением кожи и клинически не отличается от проявлений гипокомплементемического варианта. Развитие васкулита наиболее часто связано с приемом лекарственных препаратов и инфекционными заболеваниями [18].

Болезнь Бехчета является системным заболеванием и характеризуется значительным спектром поражений кожи и слизистых оболочек. Наиболее постоянным

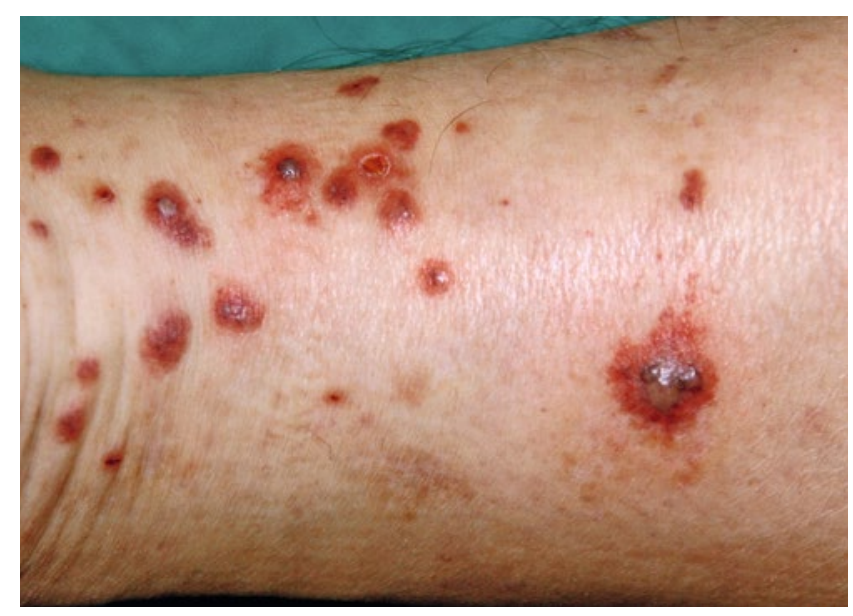

Рис. 4. IgA-васкулит: геморрагические пузыри
Fig. 4. IgA vasculitis: blood blisters

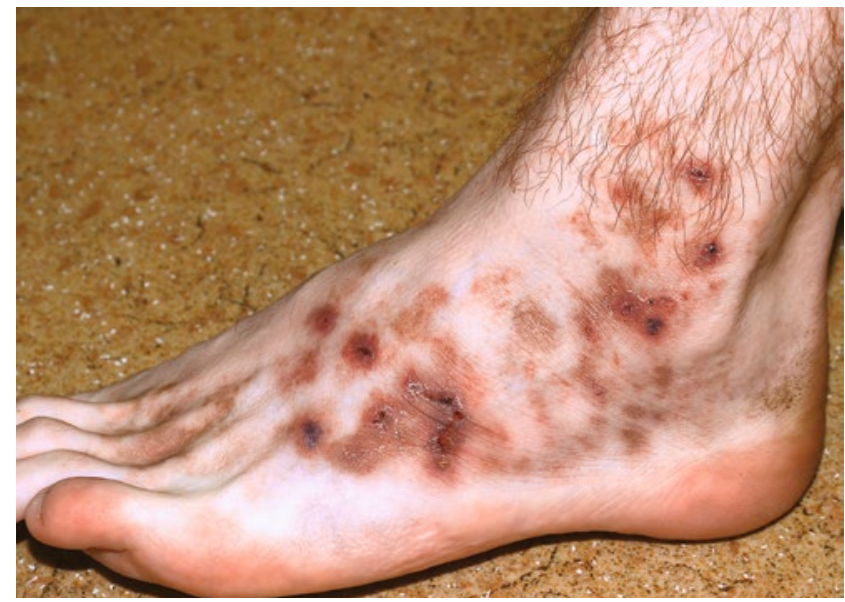

Рис. 5. IgA-васкулит: папулы с некрозом

Fig. 5. IgA vasculitis: papules with necrosis

симптомом являются рецидивирующие афты полости рта. Реже встречаются язвы в области гениталий, высыпания, подобные узловатой эритеме, тромбофлебит поверхностных вен, реакция патергии - развитие на коже в месте инъекции папуло-пустулезных элементов, акнеформные фролликулярные пустулезные и несролликулярные папуло-пустулезные высыпания. Встречается два варианта течения болезни Бехчета: васкулит с изолированным поражением сосудов кожи и слизистых оболочек и системный васкулит - с поражением глаз, ЖКТ, ЦНС, легочного ствола, с олигоартритами и др. [19-21].

При синдроме Когана изолированного поражения сосудов кожи не наблюдается. Наряду с системными проявлениями заболевания (воспаление стенки аорты и клапанов сердца, аневризма аорты) редко могут развиваться панникулиты [1, 22].

Васкулиты, ассоциированные с системными заболеваниями (CKB, ревматоидный артрит, саркоидоз 


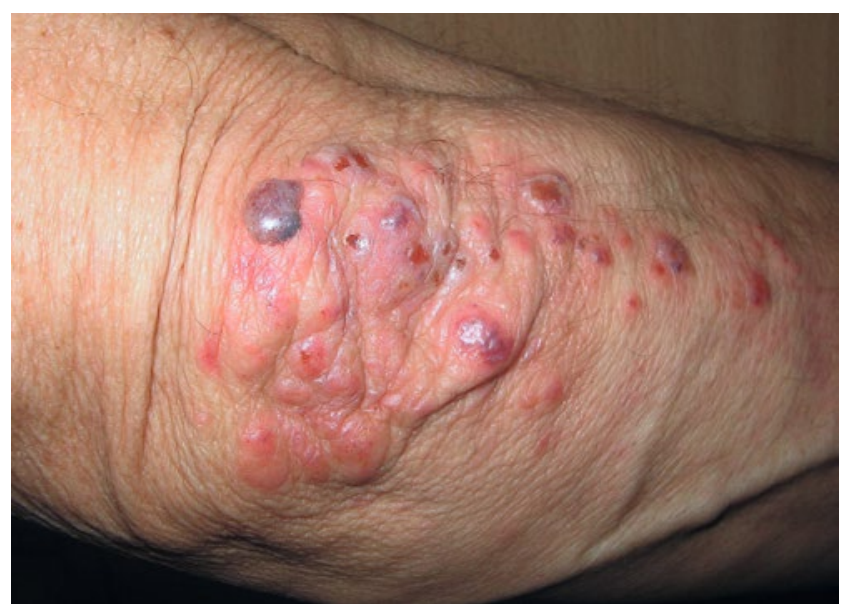

Рис. 6. Эритема возвышающаяся стойкая: плотные папулы, везикуло-буллезные элементы

Fig. 6. Erythema Elevatum Diutinum: dense papules, vesiculo-bullous elements

и др.) могут протекать с преимущественным поражением кожи (ревматоидный васкулит, ограниченный кожей) и в варианте системного воспаления кровеносных сосудов [1, 22, 41].

Узловатый васкулит (индуративная эритема Базена) может встречаться у больных туберкулезом легких или других органов, вирусными гепатитами В и С, ВИЧ-инфекцией, воспалительными заболеваниями кишечника (болезнь Крона, неспецифический язвенный колит), бруцеллезом. Заболевание чаще развивается у пожилых пациентов, распространенность среди женщин выше. На коже сгибательных поверхностей голеней развиваются болезненные узлы, которые часто изъязвляются. Язвы существуют длительное время, впоследствии формируются атрофические рубцы [23].

Эритема возвышающаяся стойкая развивается чаще в возрасте 40-60 лет. Описаны ассоциации заболевания с ВИЧ-инфекцией, IgA-гаммапатией, аутоиммунными болезнями, В-клеточной лимфомой, вакцинацией против холеры. Характерны симметричные высыпания, представленные округлыми плотными папулами с гладкой поверхностью, сливающимися в бляшки, или узлами красно-коричневого или пурпурного цвета, локализующимися на разгибательных поверхностях верхних и нижних конечностей, преимущественно периартикулярно (в проекции локтевых и коленных суставов, на кистях). По мере развития высыпаний наблюдается изменение консистенции папул от мягкой до очень плотной (рис. 6). Редко встречаются везикуло-буллезные и пустулезные элементы. Пациенты могут предъявлять жалобы на чувство зуда, жжения или болезненности кожи в области сыпи. Для заболевания характерно рецидивирующее течение, степень тяжести которого может волнообразно изменяться. В большинстве случаев через 5-10 лет наступает спонтанное выздоровление, иногда рецидивы длятся десятилетиями. Высыпания обычно разрешаются без фрормирования рубцов или атрофии. Высказываются предположения, что гранулема лица с эозинофилией и эритема возвышающая-

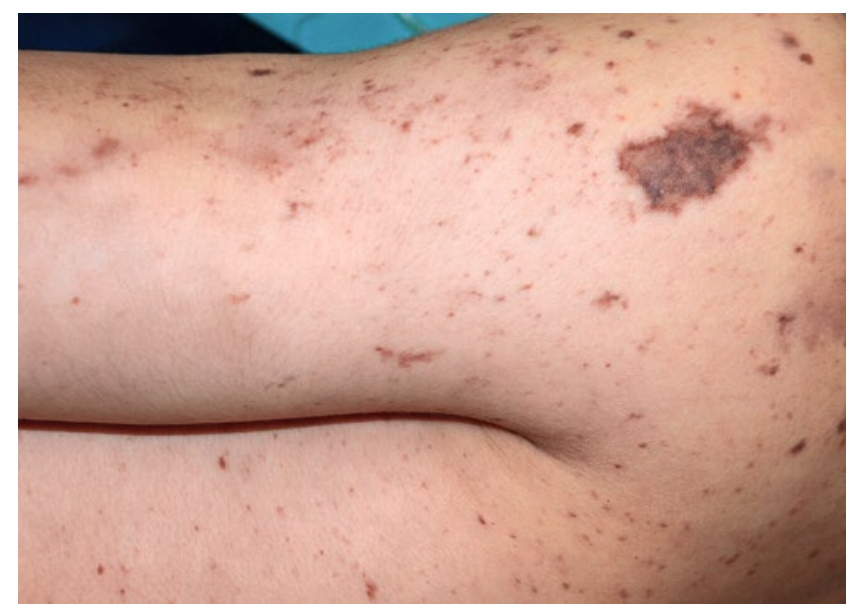

Pис. 7. Сепсис (менингококцемия): невоспалительная пурпура Fig. 7. Sepsis (meningococcemia): non-inflammatory purpura

ся стойкая - идентичные заболевания, отличающиеся анатомической локализацией [24, 25].

Септический васкулит. При сепсисе на коже больных часто появляются геморрагические пятна (пурпура), которые обычно обусловлены диссеминированной внутрисосудистой гиперкоагуляцией (ДВС-синдром) или септической эмболией мелких сосудов. У некоторых пациентов может развиваться васкулит, проявляющийся на коже единичными хаотично расположенными геморрагическими пятнами и папулами, ретикулярной пурпурой и папуло-некротическими высыпаниями [26].

Васкулит, вызванный физической нагрузкой, проявляется развитием небольших геморрагических пятен (пальпируемая пурпура) на коже нижних конечностей, возникающих после длительных фризических нагрузок или длительного нахождения в вертикальном положении. Вероятно, данное заболевание является вариантом иммунокомплексного васкулита [27].

\section{Лечение}

Лечение больных васкулитами проводится после выполнения всех необходимых диагностических мероприятий и определения нозологической принадлежности заболевания. В зависимости от этиологии васкулита применяются различные терапевтические подходы, регламентированные в соответствующих клинических рекомендациях (например, СКВ, ревматоидный артрит, болезнь Бехчета, вирусный гепатит В и С и др.). При невозможности верификации диагноза, а также при ограниченных поражениях сосудов кожи проводится симптоматическое лечение [28].

При установлении диагноза ANCA-ассоциированного васкулита назначают системные глюкокортикостероиды в сочетании с циклофоссфамидом или ритуксимабом [29].

При высокой активности заболевания вначале возможно проведение «пульс»-терапии метилпреднизолоном в дозе 30 мг/кг/сут. (не более 1000 мг) 1-3 дня. Преднизолон принимают внутрь в дозе $1-2$ мг/кг/сут. 
(не более 80 мг/сут.), в течение 8-12 недель. Затем дозу снижают на 5 мг в неделю [29].

Циклофросорамид вводят внутривенно по 15 мг/кг 1 раз в 2 недели, всего 2-3 раза. Затем по 2 мг/кг/сут. (не более 200 мг/сут.) в течение 3-12 мес. [29].

Ритуксимаб назначают внутривенно в дозе 375 мг/м² 1 раз в неделю, всего 4 инфузии [29].

При низкой активности заболевания возможно применение метотрексата в дозе 20-25 мг/нед., внутрь или парентерально [29].

После достижения стойкой клинико-лабораторной ремиссии сначала снижают дозу ГКС, затем - циклофоссрамида. После этого лечение продолжают азатиоприном или метотрексатом не менее 2 лет, а в случае гранулематоза с ангиитом или PR3-ANCA-ассоциированного васкулита - не менее 5 лет [30-32].

При преимущественном/изолированном поражении сосудов кожи чаще отмечается доброкачественное течение васкулита и агрессивная терапия обычно не требуется. Часто наблюдается тенденция к самоизлечению. По возможности необходимо устранить все триггерные факторы васкулита. Пациентам следует рекомендовать избегать длительного нахождения в вертикальном положении. Ношение компрессионного белья уменьшает отеки нижних конечностей, явления стаза в сосудах малого диаметра, способствует заживлению язв в области голеней. Применение топических ГКС уменьшает чувство жжения и зуда в области высыпаний, но не предотвращает появления новых элементов. Более половины пациентов не требуют системной терапии. Общее лечение назначают в случае тяжелого (наличие очагов некроза, язв, распространенных высыпаний), длительного (более 3-4 недель) или рецидивирующего течения васкулита [13, 28]. K препаратам выбора относятся:

- Дапсон - 50-200 мг в сутки. Препарат обладает противовоспалительным эфффектом, вызывает торможение миграции лейкоцитов. Дапсон высокоэффрективен в терапии больных эритемой возвышающейся стойкой (у $80 \%$ пациентов значительное улучшение или полное разрешение высыпаний). У пациентов с дефрицитом глюкозо-6-фросфратдегидрогеназы дапсон может вызвать развитие метгемоглобинемии и анемию вследствие гемолиза, поэтому требуется постоянный лабораторный мониторинг больных [33, 34].

- Гидроксихлорохин - 200-400 мг в сутки. Наиболее эфрфективен при уртикарных васкулитах [18].

- Пентоксифилллин - 400-1200 мг в сутки. Препарат улучшает микроциркуляцию, подавляет тромбообразование, улучшает реологические свойства крови и обладает противовоспалительным эффектом (ингибирует фоосфодиэстеразу) [18, 35].

- Индометацин - 25-50 мг 3 раза в сутки. Препарат относится к группе нестероидных противовоспалительных средств [18].

- $H_{1}$-антигистаминные препараты 2-го поколения эфффективны у 24\% больных уртикарным васкулитом. Их комбинация с системными ГКС может повысить эффективность лечения $[18,36]$.
При недостаточной эффрективности системной терапии одним препаратом возможно комбинированное лечение гидроксихлорохином или пентоксифиллином с дапсоном или индометацином [28]. Целесообразность применения антикоагулянтов и антиагрегантов (гепарина, варфарина, дипиридамола, ацетилсалициловой кислоты) не доказана, их использование может привести к развитию серьезных нежелательных явлений [13].

Системные глюкокортикостероиды назначают при недостаточной эффективности проводимого лечения или при исходно тяжелом течении васкулита. Применение системных ГКС приводит к сокращению сроков разрешения высыпаний на коже (при остром течении). В терапии уртикарного васкулита ГКС являются наиболее эффрективными препаратами - более чем у $80 \%$ пациентов их назначение приводит к выздоровлению или стойкой ремиссии. При хроническом течении $\lg$ А-васкулита использование ГКС малоэфрфективно [13, 18, 37, 38, 41].

Применяют преднизолон в дозе 0,5-1,0 мг/кг/сут. После достижения терапевтического эфрфекта дозу препарата быстро снижают [13, 37, 38].

В случае неэффективности вышеперечисленных препаратов или при наличии противопоказаний к ним назначают цитостатики: азатиоприн - 50-200 мг/сут. или меторексат - 15-25 мг/нед. [39].

Генно-инженерные биологические препараты - ингибиторы фрактора некроза опухолей- $\alpha$ (инфрликсимаб, этанерцепт), ингибиторы IL-1b/L-1 рецептора (анакинра, канакинумаб), анти-CD20 (ритуксимаб), антагонисты рецептора IL-6 (тоцилизумаб), ингибиторы IgE (омализумаб) показали высокую эффрективность в терапии торпидных васкулитов кожи, но сведений об их применении накоплено пока недостаточно [18, 40].

\section{Заключение}

Многообразие васкулитов кожи, их клиническое сходство, отсутствие четких диагностических критериев и единой терминологии обуславливают крайне сложный процесс диагностики данной группы заболеваний. Кожа является органом, который часто поражается при васкулитах. В то же время высыпания в виде пурпуры могут встречаться при нескольких сотнях заболеваний. Кожа доступна для осмотра, а проведение диагностической биопсии относительно несложно. Дерматовенеролог нередко является первым специалистом, осуществляющим диагностику васкулита. Этим обусловлены очень высокие требования к знаниям дерматовенеролога в области васкулитов. Синдромальный подход в диагностике васкулитов кожи на основании характеристики элементов кожной сыпи неминуемо приведет к объединению в одну нозологию совершенно разных заболеваний, отличающихся лечением и прогнозом. Правильный диагноз, который может быть поставлен только при условии грамотной интеграции анамнестических, клинических, лабораторных и морфологических данных, является обоснованием оптимальной терапии пациентов. 


\section{Литература/References}

1. Sunderkötter C.H., Zelger B., Chen K.R. et al. Nomenclature of Cutaneous Vasculitis: Dermatologic Addendum to the 2012 Revised International Chapel Hill Consensus Conference Nomenclature of Vasculitides. Arthritis Rheum. 2018 Feb; 70 (2): 171-184.

2. Sunderkötter C., Michl C. Cutaneous alterations in vasculitides: Part 1: Nomenclature, classification and correlation between clinical signs and histological features. Internist (Berl). 2019; Aug; 60 (8): 799—804.

3. Kluger N., Pagnoux C., Guillevin L., Frances C. Comparison of cutaneous manifestations in systemic polyarteritis nodosa and microscopic polyangiitis. Br J Dermatol 2008; 159: 615-620.

4. Criado P.R., Marques G.F., Morita T.C., de Carvalho J.F. Epidemiological, clinical and laboratory profiles of cutaneous polyarteritis nodosa patients: report of 22 cases and literature review. Autoimmun. Rev. 2016; 15: $558-563$.

5. Newell E.L., Mallipeddi R., Murdoch M.E. et al. A case of cutaneous extravascular necrotizing granuloma without systemic manifestations. Clin. Exp. Dermatol. 2007; 32: 509—512.

6. Cabral D.A., Morishita, K. Antineutrophil Cytoplasmic Antibody Associated Vasculitis. Textbook of Pediatric Rheumatology, 2016; 484-499.

7. Ramos-Casals M., Stone J.H., Cid M.C., Bosch X. The cryoglobulinaemias. Lancet. 2012; 379: 348-360.

8. Terrier B., Karras A., Kahn J.E. et al. The spectrum of type I cryoglobulinemia vasculitis: newinsights based on 64 cases. Medicine (Baltimore). 2013; 92: 61—68.

9. Gonzalez L.M., Krysicka Janniger C., Schwartz R.A. Pediatric Henoch Schonlein purpura. Internat. J. Dermatol. 2009; 48 (11): 1157-1165.

10. Langford C.A. Vasculitis. J. Allergy Colin. Immunol. 2010; 125: 216-225.

11. Rigante D., Castellazzi L., Bosco A. et al. Is there a crossroad between infections, genetics, and Henoch-Schönlein purpura? Autoimmun. Rev. 2013; 12 (10): 1016-1021.

12. Arora A., Wetter D.A., Gonzalez-Santiago T.M., Davis M.D., Lohse C.M. Incidence of leukocytoclastic vasculitis, 1996 to 2010: a population-based study in Olmsted County. Minnesota. Mayo Clin. Proc. 2014; 89: $1515-1524$.

13. Hetland L.E., Susrud K.S., Lindahl K.H., Bygum A. Henoch-Schönlein Purpura: A Literature Review. Acta Derm. Venereol. 2017; 15; 97 (10): 1160-1166.

14. Batu E.D., Sarı A., Erden A. et al. Comparing immunoglobulin A vasculitis (Henoch-Schönlein purpura) in children and adults: a single-centre study from Turkey. Scand. J. Rheumatol. 2018; 47 (6): 481—486.

15. Davis M.D., Daoud M.S., Kirby B., Gibson L.E., Rogers R.S. III. Clinicopathologic correlation of hypocomplementemic and normo-complementemic urticarial vasculitis. J. Am. Acad. Dermatol. 1998; 38: 899—905.

16. Loricera J., Calvo-Rio V., Mata C. et al. Urticarial vasculitis in northern Spain: clinical study of 21 cases. Medicine (Baltimore). 2014; 93: $53-60$.

17. Broekaert S.M., Boer-Auer A., Kerl K. et al. Neutrophilic epitheliotropism is a histopathological clue to neutrophilic urticarial dermatosis. Am. J. Dermatopathol. 2016; 38: 39—49.

18. Kolkhir P., Grakhova M., Bonnekoh H., Krause K., Maurer M. Treatment of urticarial vasculitis: A systematic review. J. Allergy Clin. Immunol. 2019; 143 (2): 458-466.

19. Kim B., LeBoit P.E. Histopathologic features of erythema nodosum-like lesions in Behcet disease: a comparison with erythema nodosum focusing on the role of vasculitis. Am. J. Dermatopathol. 2000; 22: $379-390$
20. Hamuryudan V., Hatemi G., Tascilar K. et al. Prognosis of Behcet's syndrome among men with muco-cutaneous involvement at disease onset: long-term outcome of patients enrolled in a controlled trial. Rheumatology (0xford). 2010; 49: 173-177.

21. Ugurlu N., Bozkurt S., Bacanli A., Akman-Karakas A., Uzun S., Alpsoy E. The natural course and factors affecting severity of Behcet's disease: a single-center cohort of 368 patients. Rheum. Int. 2015; 35: 2103-2107.

22. Jennette J.C., Falk R.J., Bacon P.A. et al. 2012 revised International Chapel Hill Consensus Conference Nomenclature of Vasculitides. Arthritis Rheum. 2013; 65: 1-11.

23. Pozdnyakova 0., Garg A., Mahalingam M. Nodular vasculitis a novel cutaneous manifestation of autoimmune colitis. J. Cutan. Pathol. 2008; 35 (3): 315-319.

24. Ziemer M., Koehler M.J., Weyers W. Erythema elevatum diutinum - a chronic leukocytoclastic vasculitis microscopically indistinguishable from granuloma faciale? J. Cutan. Pathol. 2011; 38 (11): 876 —883.

25. Ba W., Yang $Y$., Zheng $L$. et al. Erythema elevatum diutinum with pustule formation: An unusual finding. J. Cutan. Pathol. 2018; 45 (3): $246-248$.

26. Mahr A., Batteux F., Tubiana S. et al. Prevalence of antineutrophil cytoplasmic antibodies in infective endocarditis. Arthritis Rheum. 2014; 66 : 1672-1677.

27. Kelly R.I., Opie J., Nixon R. Golfer's vasculitis. Australas J. Dermatol. 2005; 46: 11-14.

28. Micheletti R.G., Werth V.P. Small Vessel Vasculitis of the Skin. Rheum. Dis. Clin. North America. 2015; 41 (1): 21-32.

29. Yates M., Watts R.A., Bajema I.M. et al. EULAR/ERA-EDTA recommendations for the management of ANCA-associated vasculitis. Ann. Rheum. Dis. 2016; 75 (9): 1583-1594.

30. Calich A.L., Puechal X., Pugnet G. et al. Rituximab for induction and maintenance therapy in granulomatosis with polyangiitis (Wegener's). Results of a single-center cohort study on 66 patients. J. Autoimmun. 2014; 50: 135-141.

31. Charles P., Neel A., Tieulie N. et al. Rituximab for induction and maintenance treatment of ANCA-associated vasculitides: a multicentre retrospective study on 80 patients. Rheum. (0xford). 2014; 53 (3): 532—539.

32. Thai L.H., Charles P., Resche-Rigon M., Desseaux K., Guillevin L. Are anti-proteinase-3 ANCA a useful marker of granulomatosis with polyangiitis (Wegener's) relapses? Results of a retrospective study on $126 \mathrm{pa}-$ tients. Autoimmun. Rev. 2014; 13 (3): 313-318.

33. Bech A.P., Reichert L.J., Cohen Tervaert J.W. Dapsone for the treatment of chronic IgA vasculitis (Henoch-Schonlein). Neth. J. Med. 2013; 71: $220-221$

34. Momen S.E., Jorizzo J., Al-Niaimi F. Erythema elevatum diutinum: a review of presentation and treatment. J. Eur. Acad. Dermatol. Venereol. 2014; 28 (12): 1594-1602.

35. Alquorain N.A.A., Aljabr A.S.H., Alghamdi N.J. Cutaneous Polyarteritis Nodosa Treated with Pentoxifylline and Clobetasol Propionate: A Case Report. Saudi J. Med. Sci. 2018; 6 (2): 104-107.

36. Tosoni C., Lodi-Rizzini F., Cinquini M. et al. A reassessment of diagnostic criteria and treatment of idiopathic urticarial vasculitis: a retrospective study of 47 patients. Clin. Exp. Dermatol. 2009; 34: 166—170.

37. Dudley J., Smith G., Llewelyn-Edwards A. et al. Randomised, double-blind, placebo-controlled trial to determine whether steroids reduce the incidence and severity of nephropathy in Henoch-Schonlein purpura (HSP). Arch. Dis. Child. 2013; 98: 756-763. 
38. Jauhola 0., Ronkainen J., Autio-Harmainen H. et al. Cyclosporine A vs. methylprednisolone for Henoch-Schonlein nephritis: a randomized trial. Pediatr. Nephrol. 2011; 26: 2159-2166.

39. Goeser M.R., Laniosz V., Wetter D.A. A practical approach to the diagnosis, evaluation, and management of cutaneous small-vessel vasculitis. Am. J. Clin. Dermatol. 2014; 15 (4): 299_306.
40. Bellan M., Pirisi M., Sainaghi P.P. Long-term remission of corticosteroid- and cyclophosphamide-resistant Henoch-Schönlein purpura with rituximab. Scand. J. Rheum. 2016; 45 (1): 83—84.

41. Ramos-Casals M., Nardi N., Lagrutta M. et al. Vasculitis in systemic lupus erythematosus: prevalence and clinical characteristics in 670 patients. Medicine (Baltimore). 2006; 85: 95-104.

\section{Информация об авторах}

Хайрутдинов Владислав Ринатович - д.м.н., доцент, доцент кафедры кожных и венерических болезней Военно-медицинской академии им. С. М. Кирова; e-mail: haric03@list.ru; тел.: +7 (905) 205-75-99

Белоусова Ирена Эдуардовна - д.м.Н., профрессор кафедры кожных и венерических болезней Военно-медицинской академии им. С.М. Кирова; e-mail: mailto:irena.belousova@mail.ru

Самцов Алексей Викторович - д.м.н., профессор, заведующий кафедрой кожных и венерических болезней Военно-медицинской академии им. С. М. Кирова; e-mail: mailto:avsamtsov@mail.ru; тел.: +7 (812) 271-87-81

\section{Information about the authors}

Vladislav R. Khairutdinov - Dr. Sci. (Med.)., Assoc. Prof., Assoc. Prof. of the Department of Skin and Sexually Transmitted Diseases, S. M. Kirov Military Medical Academy, Ministry of Defence of the Russian Federation; e-mail: haric03@list.ru; tel.: +7 (905) 205-75-99

Irena E. Belousova - Dr. Sci. (Med.)., Assoc. Prof., Prof. of the Department of Skin and Sexually Transmitted Diseases, S. M. Kirov Military Medical Academy, Ministry of Defence of the Russian Federation; e-mail: mailto:irena.belousova@mail.ru

Aleksey V. Samtsov - Dr. Sci. (Med.)., Prof., Head of the Department of Skin and Sexually Transmitted Diseases, S. M. Kirov Military Medical Academy, Ministry of Defence of the Russian Federation; e-mail: mailto:avsamtsov@mail.ru; tel.: +7 (812) 271-87-81 